\title{
Simple methods for detection of microborings produced by coral-associated microendoliths
}

\author{
Klaudiusz Salamon $^{1}\left[\right.$ D $\cdot$ Bogusław Kołodziej ${ }^{1} \cdot$ Vadim L. Stefanskyi $^{2}$
}

Received: 24 September 2018 / Accepted: 25 February 2019 / Published online: 12 March 2019

(c) The Author(s) 2019

\begin{abstract}
Well-preserved skeletons of Paleocene and Eocene scleractinians and octocorals (Polytremacis sp.) from Poland and Ukraine were studied to reveal microborings produced in vivo by coral-associated microendoliths. Microborings (mostly $<5 \mu \mathrm{m}$ in diameter) are hardly visible, if at all, under a petrographic microscope. Their resin casts are obtained, however, through the epoxy vacuum cast-embedding technique and observed under a scanning electron microscope (SEM). Three-dimensional resin-filled (cast) microborings are also clearly visible under SEM in acid-etched petrographic thin-sections. Backscattered scanning electron microscopy imaging (BSE) is useful for visualization of the microborings during SEM study of both etched and non-etched thin-sections. A simple but very effective method to reveal the dense network of resin casts of microborings is observations of etched thin-sections under the petrographic microscope. Fluorescence microscopy (FL), especially with application of blue and green filters (Nikon's B-1A and G-2A filter cubes), is recommended if etching thin-sections or polished samples is not possible. However, color contrast between the resin casts and the calcium carbonate of the coral skeleton was strong enough only in some examined thin-sections. The cathodoluminescence microscopy, the other method, does not require the etching of the thin-sections and is potentially useful for detection of microborings filled with calcite cement, although this technique was not applicable for the samples studied. Symbiotic coral-microendolith association (in broad meaning of the term symbiosis) is a common phenomenon in modern corals, but its fossil record is very sparse. This study shows that empty microborings can be common in fossil corals, allowing preparation of the resin casts. Some of the tested methods permit rapid detection of resin-filled microborings in thin-sections even by non-specialists, and selection of samples for SEM studies. Corals from claystones and mudstones, usually less affected by diagenesis, have higher taphonomic potential for preservation of empty microborings than corals from reef facies. The methods discussed here can be also applied for rapid detection of post-mortem microborings occurring in other substrates.
\end{abstract}

Keywords Microendoliths $\cdot$ Corals $\cdot$ Microbioerosion $\cdot$ Resin casts $\cdot$ Microscope imaging $\cdot$ Fluorescence microscope Paleogene $\cdot$ Eocene

This article is part of a Topical Collection in Facies on Bioerosion: an interdisciplinary approach, guest edited by Ricci, Uchman and Wisshak.

Klaudiusz Salamon

klaudiusz.salamon@gmail.com

Bogusław Kołodziej

boguslaw.kolodziej@uj.edu.pl

Vadim L. Stefanskyi

stefanskyi2017@gmail.com

1 Institute of Geological Sciences, Jagiellonian University, Ul. Gronostajowa 3a, 30-387 Kraków, Poland

2 Institute of Geological Sciences, National Academy of Sciences of Ukraine, 55B O. Gonchara Street, Kiev 02054, Ukraine

\section{Introduction}

Modern corals are commonly associated with boring microorganisms inhabiting skeletons during coral's life (e.g., Le Campion-Alsumard et al. 1995; Golubic et al. 2005; Tribollet 2008). The record of activity of such microendoliths (microendoliths sensu Golubic et al. 1981) in fossil scleractinians is very sparse. The only detailed reports deal with calcite-filling microborings (some of them impregnated with ferric iron), that are commonly ca. $10-40 \mu \mathrm{m}$ in diameter, thus large enough to be easily visible under a petrographic microscope (Kołodziej et al. 2012, 2016). Preliminary studies of resin and natural (ferruginous) casts of fine microborings (mostly $<5 \mu \mathrm{m}$ in diameter) produced in vivo by 
microendoliths in corals from the Paleocene of Poland and the Cenomanian of Germany revealed that microborings are common and morphologically diversified (Kołodziej and Radtke 1999; Salamon 2017; Salamon et al. 2018).

Diagenesis is one of the reasons for the sparse fossil record. Skeletons of fossil scleractinians are commonly affected by the transformation of aragonite into calcite, recrystallization or dissolution. These taphonomical processes commonly destroy the microborings. Even the microborings in modern corals may be rapidly filled with calcite cement, making their identification difficult. Preliminary studies of corals from the Paleocene (Kołodziej and Radtke 1999; Salamon 2017) and from the Eocene (this report) revealed that the microborings in fossilized corals may be common and still empty, allowing preparation of resin casts and study under the scanning electron microscope (SEM). These results indicate that the microborings left by coral-associated microendoliths are much more common in the fossil material than previously assumed. During conventional microscopic observations, even under high magnification, detection of microborings may be difficult, if not impossible, especially for researches not familiar with this topic. Cooperation with non-specialists, especially with coral taxonomists, is desirable to select proper material for detailed studies. Studies of standard SEM samples are timeconsuming, but results are uncertain. Moreover, application of destructive methods may be impossible or limited in the case of samples (especially thin-sections) from museum collections. Therefore, there is an obvious need for simple and rapid methodology. However, whenever possible, the resin casting technique is the main method for study of microborings and their producers.

\section{Material}

Upper Paleocene (Tanetian) Babica Clays from the Skole Unit of the Polish Outer Carpathians (southern Poland), discovered by Bolesław Kropaczek in 1917 (see Studencka 1986), are lithologically diversified, dark-grey, sediments of submarine debris flows, mostly sandy mudstones, bearing exotic crystalline and sedimentary pebbles as well as redeposited fossils (Rajchel 1990). Babica Clays contain relatively rich microfossils (Szczechura and Pożaryska 1974) and small, fragile macrofossils, first of all, bivalves and gastropods (Krach 1969; Studencka 1986). According to Krach (1969), the molluscs lived in a shallow-water environment, no deeper than ca. $75 \mathrm{~m}$, and a temperature of at least $20^{\circ} \mathrm{C}$. The corals studied are from deposits exposed in the Kosina stream, south of Babica village near Rzeszów (Fig. 1a, b). Well-preserved corals, commonly with aragonitic skeletons, are both colonial (but not reef builders) and solitary forms. The colonies and their fragments usually attain $3-5 \mathrm{~cm}$ in

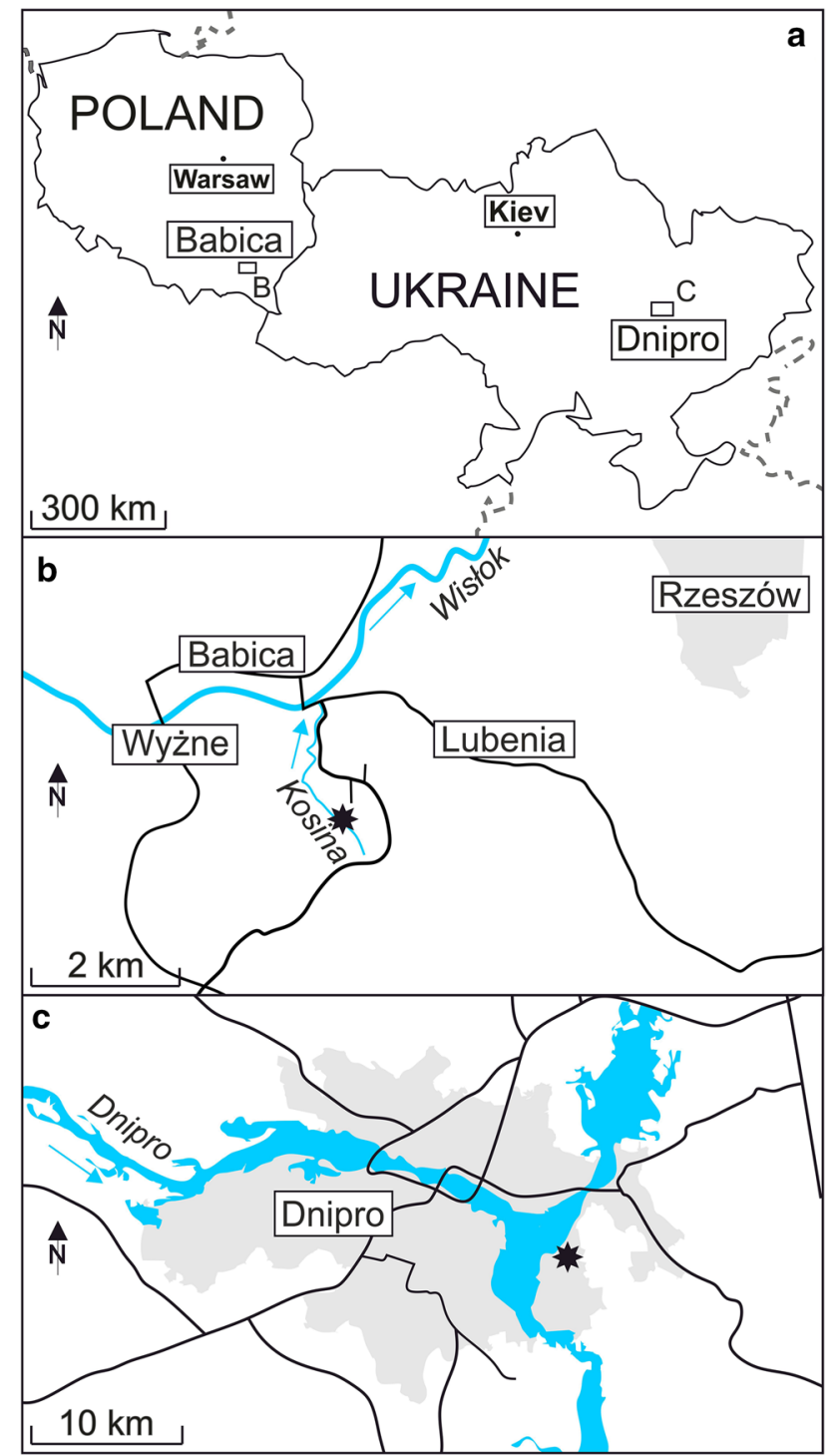

Fig. 1 Location of the sampling area: a General map, b Kosina stream near Babica in Poland, and c Rybalsky quarry in Dnipro, Ukraine. Outcrops locality marked with the asterisk

diameter (max. $10 \mathrm{~cm}$ ). Preliminary studies revealed about 20 scleractinian species representing colonial genera (mainly Actinastraea and Actinacis) and solitary forms (mainly Caryophyllia, Trochocyathus, and Balanophyllia) (Kołodziej and Stolarski 2000). Specimens of Polytremacis sp., belonging to the suborder Octocorallia (family Helioporidae), are especially common. The space between skeletal elements is empty or filled with sediment and/or calcite cement. Additionally, we studied some corals from Babica Clays collected by Wilhelm Krach and Władysław Rogala. This collection (A I-113) is housed in the Geological Museum at the Institute of Geological Sciences, Polish Academy of Sciences, Kraków. 
Upper Eocene Mandrykovka Beds have been established by Nikolay A. Sokolov (see Stefanskyi et al. 2011) on the right bank of the Dnieper River, where they are distributed locally in the southern part of the Dnipro city (until 2016: Dnipropetrovsk), eastern Ukraine. This area is located in the junction of the Ukrainian Shield (Ukrainian Crystalline Massif) and the Dnieper-Donetsk Aulacogen. The material studied comes from the Mandrykovska Beds (up to $6 \mathrm{~m}$ in thickness) exposed in the Rybalsky quarry in Dnipro, where Archaean crystalline rocks are explored (Fig. 1a, c). The Mandrykovka Beds are member of the Obukhov Suite of the Obukhov Regiostage (Makarenko et al. 1987), and are considered as Priabonian in age (NP 19 zone and the base of the NP 20 zone; Veselov et al. 1974). Lithologically, the Mandrykovka Beds are yellowish or light grey, coarse, poorly lithified, slightly clayey, detrital limestones (traditionally called calcareous detrital sands). They contain diverse microfossils and small, fragile macrofossils, among others foraminifera, corals, bryozoans, small brachiopods, worms, crustaceans, gastropods, bivalves, and fish remains. They represent various ecological niches of the warm-water, normal saline, high-energy littoral zone deposited in a beach environment (e.g., Veselov et al. 1974; Nosovsky 1978; Kuzmicheva 1987; Stefanskyi et al. 2011; Stefanskyi 2015a, b; Bitner and Müller 2017). The fossils are often excellently preserved, although the thin fragile bivalve and gastropod shells are commonly crushed and certainly many of them are lost in the fossil record. The Mandrykovka Beds contain at least 22 species of colonial (mostly Astreopora sphaeroidalis, Montipora migatschevae, Cyathoseris infundibuliformis) and solitary corals (mostly Trochoseris helianthoides, Trochosmilia corniculum, Paracyathus crassus) as revealed studies by Kuzmicheva (1987). The colonial coral specimens (mostly their fragments) are small (mostly $2-4 \mathrm{~cm}$, $\max .8 \mathrm{~cm}$ in diameter), well preserved, and usually with aragonitic skeletons. The space between skeletal elements is usually empty, devoid of sediment or cement.

Further on in the paper, the material from the Babica Clays and from the Mandrykovka Beds are mostly referred to as the Paleocene corals and the Eocene corals, respectively. The specimens are deposited at the Institute of Geological Sciences, Jagiellonian University, Kraków.

\section{Methods}

The various preparation and microscopic methods, useful for detection of the microborings, was tested in sequential order (Fig. 2). Examination of the properly prepared samples involved observation under (i) the petrographic microscope, (ii) the fluorescence microscope (FL), (iii) the cathodoluminescence microscopy (CL), and (iv) SEM includes the secondary electrons (SE) as well as the backscattered electrons
(BSE) imaging. The proper sequence of steps is helpful for the complex study and comparison of images of exactly the same area without any interaction between the methods. In some cases, non-removed residue of the carbon coat (for SEM analysis) may preclude the observation under the petrographic microscope, whereas etching the samples makes it impossible to observe the possible relationship between microborings and microstructure of skeleton.

The preliminary results of the vacuum cast-embedding and SEM observations of entire coral skeletons of Upper Paleocene Babica Clays and Upper Eocene Mandrykovka Beds material revealed the presence of abundant resin cast microborings produced during the coral's life. The present paper is based on studies of about 17 corals from the Paleocene and nine skeletons from the Eocene. However, to clarify the presented results, two specimens are documented: (i) the Paleocene octocoral Polytremacis sp., ca. $45 \times 40 \times 35 \mathrm{~mm}$ (general morphology in thin-section: Fig. 3a) and (ii) the Eocene scleractinian solitary coral Trochosmilia corniculum, ca. 38 in diameter $\times 20 \mathrm{~mm}$ in height (general morphology: Fig. 3d).

\section{Sample preparation}

Two types of the coral samples were studied: (i) standard thin-sections not covered by a glass slide $(27 \times 40 \mathrm{~mm}$ in size) and (ii) small cuboid-shaped coral pieces (ca. $10-20 \mathrm{~mm}$ in size). Application of the vacuum cast-embedding technique is required to prepare both samples for study. The coral specimens were cut with a diamond blade for cuboid-shaped samples. To avoid mixing the microborings produced by the symbiotic microendoliths with those produced post-mortem, the studied transverse and vertical sections are from the middle part of the coral colony and the corallum of the solitary specimen. The sections are oriented with the longest axis parallel or perpendicular to the growth direction of the coral.

After cutting, the coral skeletons were cleaned in an ultrasonic bath with deionized water and dried at $80^{\circ} \mathrm{C}$. A crucial part of the sample preparation was an impregnation with epoxy resin in a vacuum chamber in compliance with the resin casting technique developed by Golubic et al. (1970), and modified by other authors (Nielsen and Maiboe 2000; see also Wisshak 2006, 2012). The modification includes a different type of epoxy resin and a variation in the application procedure with a vacuum chamber. Nielsen and Maiboe (2000) used the Epofix kit (contains bisphenol A diglycidyl ether), while Wisshak (2006) "high viscosity resin" (Struers SpeciFix-20 or Araldite BY158), thus an application of acetone was not required as in the original method of Golubic et al. (1970). A two-component, low-viscosity resin Araldite 2020 epoxy set (the resin and the hardener) with a diluter (thinner) was used in our case. The mixture was embedded 
Fig. 2 The flowchart shows, in a sequential order the procedure, the preparation steps and the analyses for the two types of samples

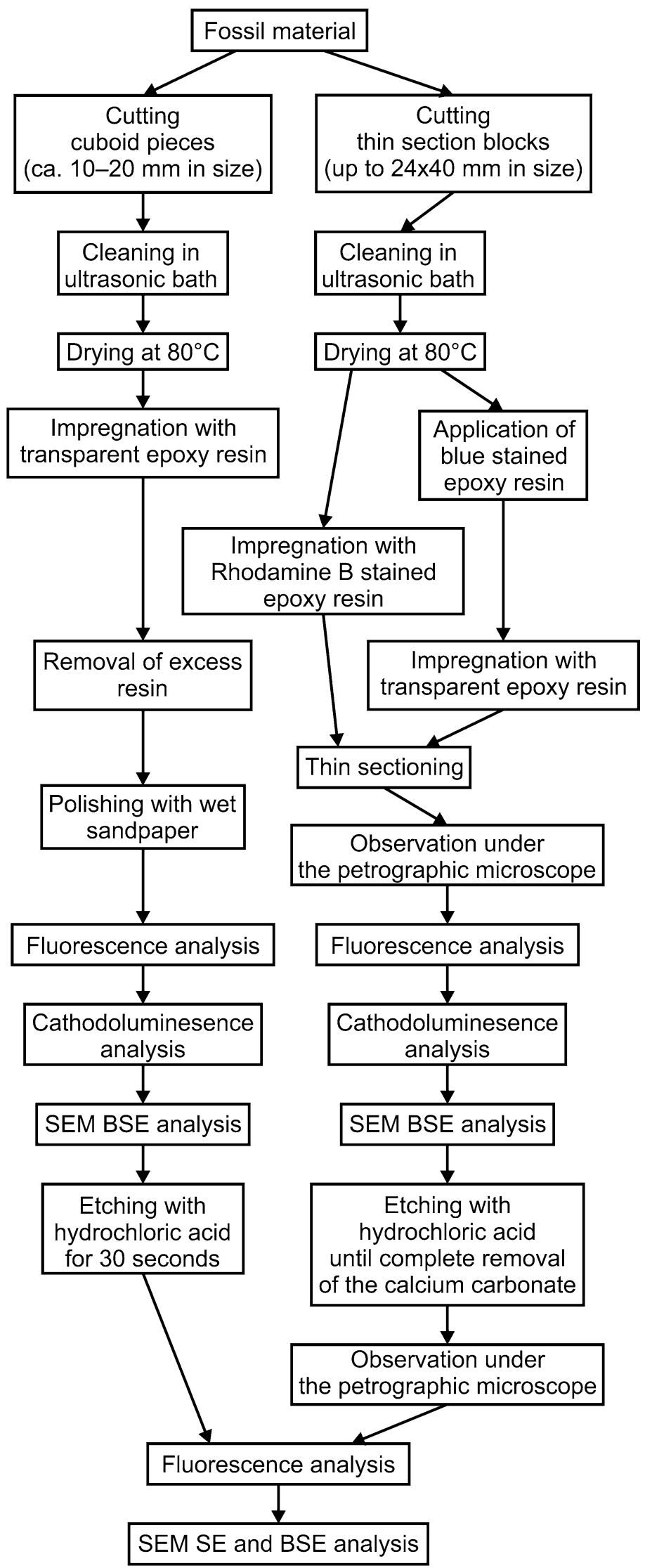



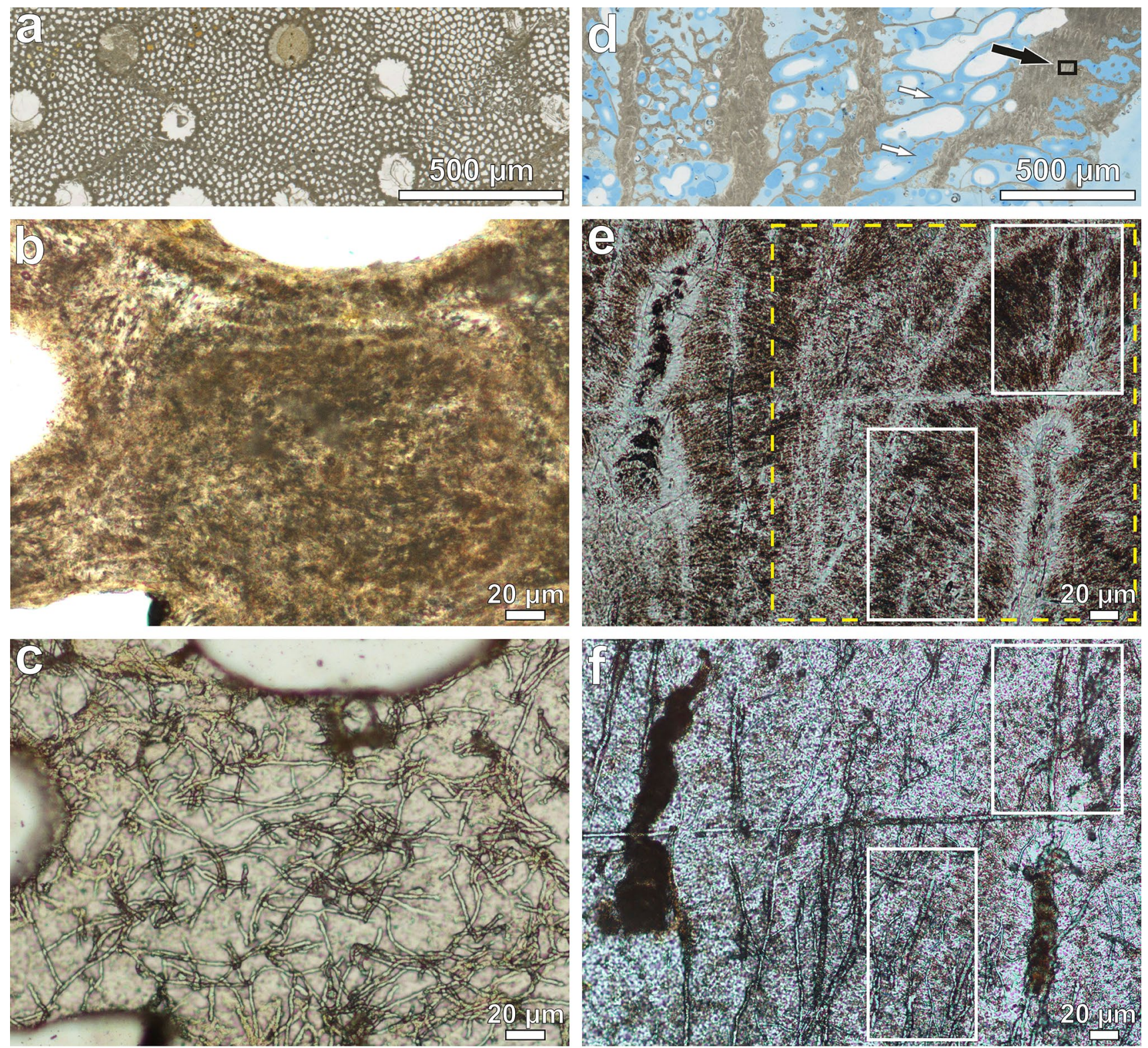

Fig. 3 Coral skeletons and microborings under the petrographic microscope. a-c Paleocene sample from the Paleocene Babica Clays. d-f Eocene sample from the Eocene Mandrykovka Beds. a General morphology of the octocoral Polytremacis sp. in the transverse section showing the corallites and the coenosteum. b Fragment of the skeletal coenosteum of Polytremacis sp. without visible microborings. c Acid-etched (decalcified) coenosteum with dense network of resin-cast microborings. d General morphology of Trochosmilia cor-

niculum in the longitudinal section. Fragment of the septum enlarged on Fig. 3e, f is outlined. Small arrows indicate intraskeletal space (between dissepiments), which was filled with the blue-stained resin, while the remaining part is filled with the standard resin. e Fragment of the septum with hardly visible microborings. f Resin casts of microborings under the petrographic microscope after dissolution of the carbonate calcium. e, f Outlined rectangles by white and dotted (yellow) lines correspond to images shown in Figs. $4 \mathrm{e}$ and $5 \mathrm{~d}-\mathrm{f}$

during a one-stage casting. Organic matter and remains present in modern, fresh specimens must be removed, but fossil material does not require it (Golubic et al. 1970).

In terms of the composition of the resin, three different types of the samples were prepared using: (i) a transparent resin, (ii) a Struers' Blue Dye (blue-stained epoxy resin), and (iii) a Rhodamine B as a fluorescence dye (fluorophore). The casting process was slightly different for each

type of sample. The transparent resin and the resin with the Rhodamine B were poured during one application. The blue-dyed resin was applied not during one, but in a two-stage casting. A first layer of the blue-dyed resin was applied on the specimen with a brush. Next, the sample was poured by the transparent resin up to full covered of the skeleton. 
After the resin fully hardens (typically a few days), 30- $\mu \mathrm{m}$-thick polished, uncovered thin-sections were prepared. The cuboid-shaped samples were not sectioned, only the excess resin was removed to expose the skeleton, and then polished with wet 2000 grit (P2000) sandpaper. Our studies of the microborings in the Paleocene corals were also performed on thin-sections prepared in the 1990s, possibly without the application of a vacuum chamber.

None of the thin-sections studied were covered by a glass slide. Observations were performed on non-etched thin-sections as well as thin-sections etched with diluted hydrochloric acid (3-3.5\%) and cleaned in deionized water. Because of the low thickness of the thin-section, the time required for complete removal of the calcium carbonate is short, approximately up to $30 \mathrm{~s}$ for the Paleocene material, to less than $4 \mathrm{~s}$ in the case of the exceptionally well preserved Eocene corals. The cuboid-shaped samples of the Paleocene corals were etched superficially for $30 \mathrm{~s}$. A shorter exposure to the acid results in inadequate dissolution of the carbonate skeleton (exposed parts of the resin casts do not allow for ichnotaxonomic analysis), whereas a longer time triggers too deep of an etching, resulting in a high relief of resin casts network, a low-quality SEM image and making preparation difficult.

\section{Microscopic methods}

\section{Petrographic microscope}

The thin-sections were observed under the multipurpose, petrographic Nikon Eclipse $\mathrm{N} i$-U microscope with $4 \times, 10 \times$, and $20 \times$ magnification objective lenses and NIS-Elements BR software.

\section{Fluorescence microscope}

The Nikon microscope used for standard petrographic observations allows for epifluorescence studies of the thin-sections as well as the non-transparent cuboid-shaped etched or the non-etched samples. In an epifluorescence microscope, the light source is located above the specimen and objectives are used for illumination and imaging a sample. Excitation and emission light is separated by a dichroic mirror, composed of a barrier and excitation filters in replaceable cubes (knows as filter combination blocks or filter cubes), that separate selected wavelengths (see Lichtman and Conchello 2005). The three Nikon's fluorescence filter cubes used were: ultraviolet (UV-1A), blue (B-1A), and green (G-2A). Two types of images were taken and compared-the first set of images with different exposure time suitable for the filter cube to reach similar brightness, and the second set with the same time during all pictures performing.

\section{Cathodoluminescence microscope}

The thin-sections were also subjected to cathodoluminescence analysis with the Nikon Eclipse 50i petrographic microscope and the Cambridge Image Technology (CITL) $8200 \mathrm{Mk}$ three cold cathode set. The equipment was operating at an electron beam voltage of $15-17 \mathrm{kV}$ and electric current of 400-500 mA during the tests.

\section{Scanning electron microscope}

The etched or polished samples (including thin-sections) were coated with carbon in the Cressington 208carbon vacuum coater and observed under the HITACHI S-4700 Scanning Electron Microscope detecting secondary electrons (SEM SE, the most common SEM analysis) as well as backscattered electrons (SEM BSE). The SEM SE analysis of the etched samples was the last step of the tests, because of the carbon coating, irremovable from fine and fragile castings. The carbon layer applied before the SEM BSE analysis was partly removed with propanol and then vanished with carbonates during etching of the samples. The laboratory studies were performed at the Institute of Geological Sciences, Jagiellonian University in Kraków.

\section{Results: microborings studied by different methods}

\section{Microborings under the petrographic microscope}

As will be shown in further sections, SEM observations and other methods revealed abundant microborings in the both Paleocene and Eocene corals. They are, however, mostly not visible (Fig. 3b), ambiguous, or hardly visible (Fig. 3e) when the thin-sections are observed under the petrographic microscope, even at high magnification. In terms of the density of the resin casts of microborings, the image in Fig. $3 \mathrm{~b}$ is representative of the most of the studied Paleocene corals. We observed clearly visible microborings in some of the thin-sections, however, they could not be noticed by nonspecialists, for example researchers focused on coral taxonomy. The microborings in Fig. 3e (the Eocene coral) could be interpreted as thin fractures or even as artifacts related with thin-section preparation.

The application of a blue dye powder in the resin enhanced visibility for only some of the microborings. Color contrast between the blue-dyed resin and the coral skeleton, observed under petrographic microscope, could be helpful in noticing resin-filled microborings. Compared with examples known from literature, the image of the microborings in thin-sections, prepared with the application of bluestained resin, was usually unsatisfactory due to incorrect 
methodology (see Discussion). This is visible even during observations under low magnification. The blue-stained resin only partially fills intraskeletal spaces, even the large ones (Fig. 3d).

Spectacular results were obtained when the acid-etched thin-sections were observed under the petrographic microscope. The resin casts of the microborings are abundant and clearly visible (Fig. 3c, f), showing similarity to filaments of microendoliths in modern decalcified coral samples (e.g., Verbruggen and Tribollet 2011, their Fig. 1c). Decalcification of the entire 30 - $\mu$ m-thick skeleton in thin-sections causes much more of the resin casts to be observed with some focus adjustments. In particular, the image of the skeleton of the Paleocene Polytremacis sp., without the recognizable microborings in Fig. 3b, strongly contrasts with the dense network resin casts revealed in the same part of the acid-etched thin-section (Fig. 3c).

In contrast to post-mortem microborings in corals and other substrates, where microborings attain depth commonly only ca. $0.5-1 \mathrm{~mm}$, microborings produced by coralassociated microendoliths occur through an entire skeleton. Therefore, studies of vertical sections evidently indicate that microborings were produced in growing corals, not postmortem (e.g., Le Campion-Alsumard et al. 1995).

\section{Microborings under SEM}

The last applied method was a study of the morphology of the etching samples under SEM SE. The results are, however, presented earlier to show that the microborings are abundant in the samples studied, that strongly contrasts with observations under the petrographic microscope. Figure $4 \mathrm{a}$ shows the SEM SE image of abundant, empty microborings within the coenosteum (reticulate, porous skeletal material between the corallites) of the Paleocene Polytremacis sp., while Fig. 4b shows the resin casts of the microborings in the etched cuboid-shaped sample, with abundant Ichnoreticulina elegans (Radtke 1991) and Saccomorpha clava Radtke 1991. The abundance and distribution of resin-filled microborings are also visible (although do not allow taxonomic determinations) even when the non-etched thin-sections were observed under SEM BSE (Fig. 4c).

Preparation of the cuboid-shaped samples is a faster and cheaper method of preparation for SEM (SE and BSE) studies than preparing the thin-sections. However, SEM studies of the three-dimensional resin casts can use the acid-etched thin-sections (or their fragments), which were already prepared, for example, for study of coral taxonomy (Fig. 4d, e). Study of the resin casts, revealed in the thin-sections, allowed for the distinguishing of the Paleocene corals following ichnotaxa: I. elegans, Conchocelichnus seilacheri Radtke et al. 2016, Scolecia filosa Radtke 1991, rarely $S$. clava and microborings similar to Rhopalia catenata Radtke
1991 (Salamon 2017). Initial studies allowed for the distinguishing of I. elegans and S. filosa in the Eocene corals. Taxonomic determinations were made with regards to Radtke (1991, 2016).

In the 1990s, observations were also performed on etched thin-sections (Paleocene corals), which were probably prepared without the application of a vacuum chamber, also the calcium carbonate in the thin-sections was not completely dissolved. Figure 4f-g (scanned pictures made in 1990s) shows that the density of resin casts is much lower than in the case of the etched thin-sections prepared with the application of the vacuum cast-embedding technique and with the complete decalcification of the coral skeleton. Only some microborings were filled with the resin (or exposed from the calcium carbonate), what is particularly visible on Fig. $4 \mathrm{~g}$, where long casts of the microborings are rare and concentrated in the central parts of septum.

\section{Microborings under the fluorescence microscope}

Observations of the thin-sections under the fluorescence microscope revealed that the microborings are more abundant and their images have been improved in comparison to the image obtained by petrographic microscope. The colors, intensity of illumination, and contrast between the carbonate skeleton and the resin were dependent on the filter cube. In general, the ultraviolet excitation light (filter UV-1a) causes blue light emission of coral skeletons and the resin (filling microborings and the space between skeletal elements). The blue excitation (filter B-1A) causes green or yellow emission, while the green excitation (filter G-2A) causes red emission.

When the blue excitation filter cube was applied, the resin casts in the Paleocene corals showed green or yellow-green to brown-green color (Fig. 5a, b). The fluorescence microscopy revealed many more resin casts when the etched thinsections were observed (Fig. 5c). In contrast, the microborings in the Eocene corals were more visible when the green filter cube was applied (filter G-2A) (Fig. 5e), than when the blue one (filter B-1A) was used (Fig. 5d). The ultraviolet light (filter UV-1a) was also tested, but blue emission in both the Paleocene and the Eocene samples was mostly weak and pale. Bright red emission of the resin casts is clearly visible on the dark red carbonate skeleton background (Fig. 5e). In contrast to the Paleocene corals, during observations of the etched thin-sections of the Eocene corals, slightly brighter colors were emitted when the blue filter cube was applied (Fig. 5f).

The addition of Rhodamine B as a fluorescent dye had no significant influence on the contrast enhancement, thus has not improved detection of the microborings, resulted only in general increased of the illumination intensity of the resin-filled microborings and the coral skeleton. 

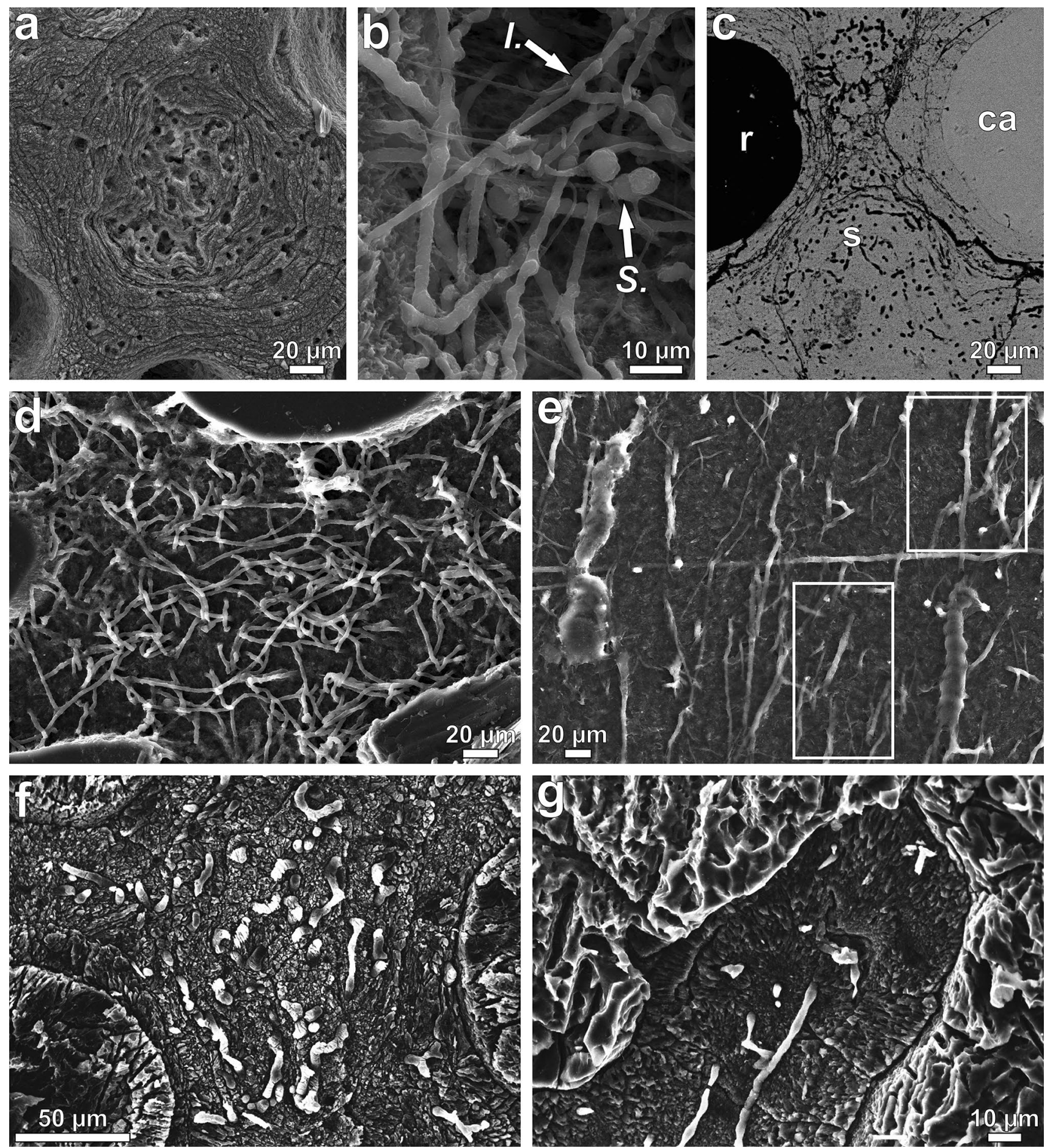

Fig. 4 SEM images of microborings in the Paleocene coral Polytremacis sp. (a-d, e-f) and in the Eocene coral Trochosmilia corniculum (e) obtained during observations of a non-etched coral piece (a), etched cuboid-shaped sample (b), as well as non-etched BSE image (c) and etched thin-sections (d-g). a Empty microborings in the coenosteum. e Resin casts of microborings in the cuboid-shaped sample: Ichnoreticulina elegans (I) and Saccomorpha clava $(S)$. c Microborings within the skeletal coenosteum (s) under the backscattered scan-

ning electron microscopy. The empty space within the coenosteum is partly filled with calcite (ca) and epoxy resin (r). d, e The resin casts exposed after dissolution of coral skeletons (etched thin-sections). $\mathbf{f}, \mathbf{g}$ The resin casts exposed after partial dissolution (etched thin-sections) of the coenosteum (f) and in the septum of undetermined colonial coral $(\mathbf{g})$. Note that the density of the microborings is lower than in Fig. $\mathbf{d}$ and $\mathbf{e}$ 

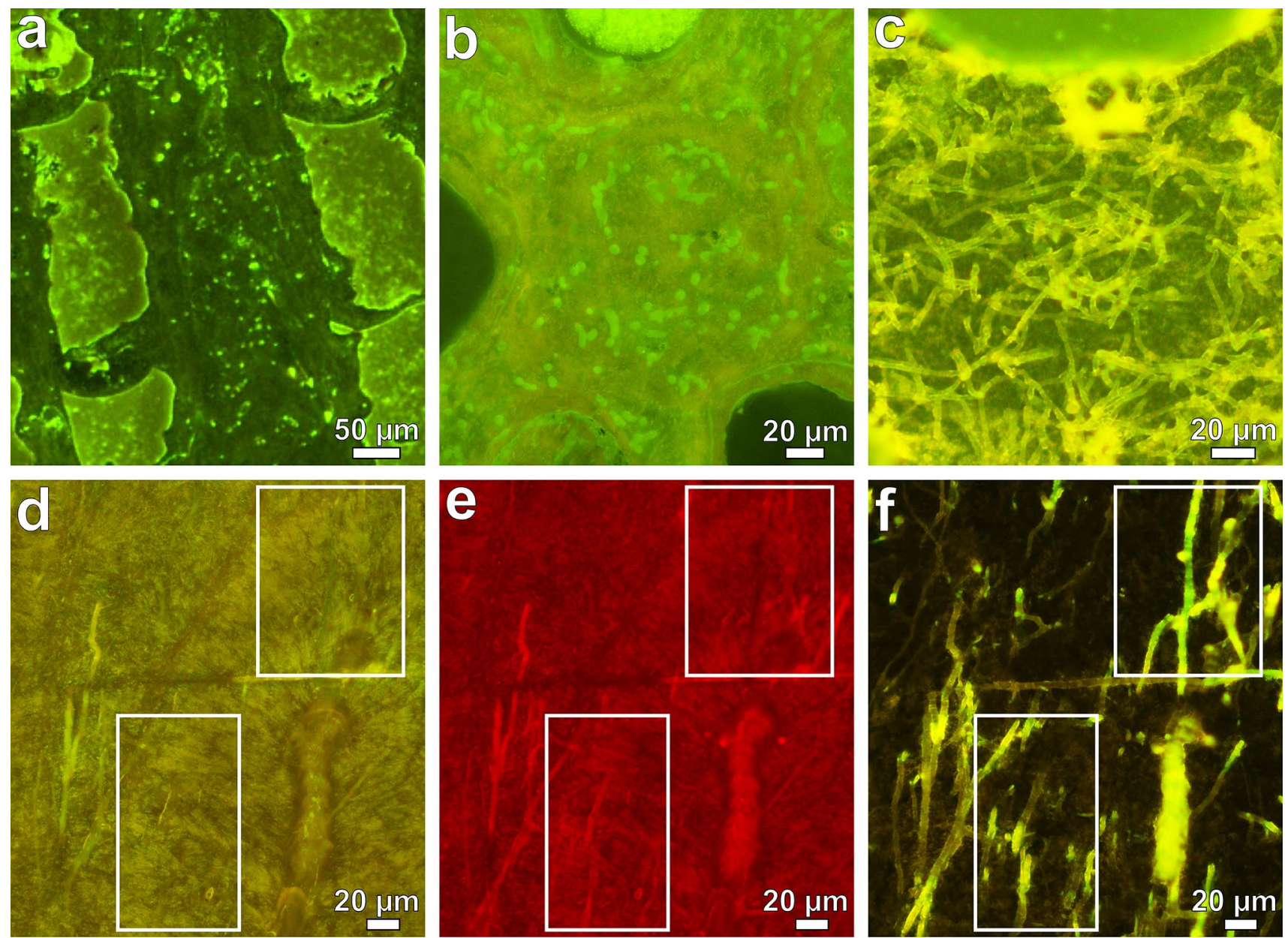

Fig. 5 Fluorescence microscopy images of resin-filled microborings from the Paleocene Polytremacis sp. (a-c) and in the Eocene Trochosmilia corniculum (d-f). a-c Microborings in Polytremacis sp. in the longitudinal (a) and transverse sections (b, c). Fluorescence image in $\mathbf{c}$ shows the resin casts after dissolution of the coral skeleton in the thin-section. In the original, color version of images, the resin casts show green $(\mathbf{a}, \mathbf{b})$ and yellow-green $(\mathbf{c})$ color. The coral skeleton is darker. d-f Fluorescence images of the resin casts in the coral sep-

Summarizing, the fluorescence microscopy was applicable only for some studied thin-sections (ca. 60\% for the Paleocene and ca. $50 \%$ for the Eocene material). In the other studied thin-sections, the color contrast between the resin replicas of the microborings and the calcium carbonate of the coral skeleton was not strong enough. In the case of the Paleocene corals, the best results were obtained with the thin-sections prepared during one session (see Fig. 5a-c), although according to the technician the same epoxy resin was applied. Unknown characters in this batch of resin increased its fluorescence documented in Fig. 5a-c. tum of Trochosmilia corniculum in vertical sections. Outlined areas are enlargements corresponding to rectangles in Figs. 3e, f, and $4 \mathbf{e}$. Different images of resin casts of microborings revealed by the application of green filter cube (d), blue filter cube (e). f The resin casts are better visible due to thin-section etching. In the original, color version of images, the casts show yellow-green (d), red (e) and bright yellow (f) color. The coral skeleton is darker, and in $\mathbf{f}$ is dark brownish

\section{Observations under cathodoluminescence microscope}

The CL view of the coral skeleton and resin show similar, poor luminescence, therefore, the microborings could not be distinguished. The application of CL is based on diversified luminescence related with the presence of mostly $\mathrm{Mn}^{2+}$ (main luminescence activator) and $\mathrm{Fe}^{2+}$ (main luminescence quencher) (Pagel et al. 2000). Because there was no contrast between the rock components and the resin (that is the coral skeleton and microborings), this method was not applicable for the detection of the microborings. 


\section{Discussion and conclusions}

\section{Significance of studies of coral-associated microendoliths}

Microboring endoliths (microendoliths) are common in dead modern and fossil corals. Like in other carbonate substrates, they significantly contribute to biodestruction processes, and formation of fine-grained sediments (Vogel et al. 2000; Tribollet 2008; Tribollet et al. 2011). The distribution ranges of individual taxa have implications for paleodepth reconstructions (Perry and Macdonald 2002; Vogel and Marincovich 2004; Chazottes et al. 2009).

Microendoliths inhabiting the skeletons of live, growing corals are a particular green algae (dominantly Ostreobium quekettii), less commonly rhodophytes, cyanobacteria and fungi. Symbiosis of microendoliths with other live calcifying organisms is not a common phenomenon. Apart from scleractinian corals, it was recognized in crustose coralline algae (Tribollet and Payri 2001) and hydrozoan stylasterids (Pica et al. 2016). There are no data about such microendoliths in modern octocorals, but they were described in representatives of Polytremacis, the genus similar to the modern Heliopora (Kołodziej and Radtke 1999; Salamon 2017).

Although the discussed microendoliths contribute to bioerosion, their principal significance is different than the microendoliths boring in dead substrates. Phototrophic endoliths appear to be beneficial for their live hosts, while fungi often have a parasitic relationship with their hosts (e.g., Le Campion-Alsumard et al. 1995; Golubic et al. 2005; Tribollet 2008; Verbruggen and Tribollet 2011). $O$. quekettii can facilitate coral survival during bleaching events (Fine and Loya 2002). It was hypothesized that periodic endolithic algal blooms in coral skeletons may represent periods of low-level stress. Algal banding (originally green) may be a more sensitive proxy for low-level stress periods (but not for severe bleaching events) than skeletal growth rates (Carilli et al. 2010). The fungi in coral skeletons have been interpreted as potentially pathogenic under environmental stress (Golubic et al. 2005). Therefore, the study of coral-associated microendoliths and traces of their boring activity in modern, subfossil, and fossil material have-among others-environmental and paleoenvironmental implications.

\section{Fossil record and recommended simple study methods}

There is a significant gap in knowledge on the fossil record of the coral-microendolith's symbiotic association in terms of ichnotaxonomy of microborings, their producers and occurrences in corals of different age and different environmental settings. Detailed studies concerned only with limited material and localities (Kołodziej et al. 2012, 2016), but work in progress indicates that, in fact, the fossil record is much more common (Salamon 2017, Salamon et al. 2018, Salamon, unpublished data). There are also rare reports of microborings interpreted as being produced in vivo in Paleozoic corals (Tabulata, Rugosa) and stromatoporoid sponges (Risk et al. 1987; Elias and Lee 1993), but SEM images of the microborings were not documented there.

In contrast to significant progress in recognizing genotypic diversity of Ostreobium quekettii (Gutner-Hoch and Fine 2011), there is poor documentation of their traces, including morphological diversity and distribution patterns within particular parts of a colony, skeletal elements, and relation to macroscopically visible banding within the skeleton.

The application of the discussed microborings in paleoenvironmental interpretation requires data from the study of coral samples of different ages, taxonomies, and from different sedimentary settings. Unfortunately, photographs in papers on coral taxonomy do not allow for evaluation of whether the microborings are present. Most of the corals in our study came from the Mesozoic reef facies, where traces produced by the coral-associated microendoliths were very sparse (see Kołodziej et al. 2012, 2016). On the Great Barrier Reef, early marine cements can be precipitated (also in microborings) within days to weeks (Nothdurft and Webb 2009). Previous studies (Kołodziej and Radtke 1999; Salamon 2017), unpublished studies by Salamon, and the present study indicate that the chance to find empty microborings in corals is higher in samples of younger age (Cenozoic) coming from poorly lithified sediments (claystones, mudstones). However, this is not always the case. For example, well-preserved Miocene corals from the Korytnica Clays in Poland (Roniewicz and Stolarski 1991) contain only rare microborings revealed by resin cast. In contrast, aragonitic Oxfordian-Kimmeridgian corals preserved in Pleistocene glacial sediments (Roniewicz 1984) contain quite common microborings (but with lower density compared to the material described here) produced by symbiotic microendoliths permitting preparation of resin casts (Salamon, unpublished). The application of the simple methods tested in our paper should be first focused on samples poorly affected by diagenesis.

Many more coral collections must be studied to reveal specimens with microborings. Cooperation with coral specialists is desirable. These researchers need to have principal knowledge on the appearance of microborings produced by the coral-associated microendoliths and the knowledge of the simple, rapid methodology. 
Our studies show that a simple, but very effective, method to reveal the dense network of the microborings is the observation of acid-etched thin-sections under a petrographic microscope. The density of the resin casts is nearly comparable to those revealed by SEM, although ichnotaxonomic studies are, of course, not possible. Due to incorrect preparation of thin-sections, application of the blue-stained resin was not successful in our studies, but this method is helpful in the documentation of microborings distribution in corals or other substrates (see Wisshak 2012).

Fluorescence microscopy is recommended when only limited thin-sections or polished samples are available, and etching is not possible. This method was applicable only for some samples studied. It is necessary to test which filter cubes are proper for the samples; in the case of our material, it was the blue and the green filters (Nikon's B-1A and G-2A filter cubes). This method significantly increased the image of the microborings when the etched thin-sections were observed. The addition of a fluorescent dye could increase the detection of the resin-filled microborings in standard thin-sections, but this requires matching the proper dye and preparing the special resin mixture. In the literature, there are few reports about the application of this method in the study of microborings (Försterra et al. 2005). As a more sophisticated methodology, for example, the application of a fluorescence and a confocal scanning laser microscope is used by biologists to detect the distribution patterns of modern microendoliths (Casanova Municchia et al. 2014).

The addition of the cheap and easily available fluorophore Rhodamine B has not worked in the case of our material. A more complex fluorescent dye could increase the detection of the resin-filled microborings, but this requires matching a proper dye and preparing the special resin mixture as some tests show, although not applied to microborings (e.g., McFadden et al. 2017). The fluorescence-based methods may be helpful in the documentation of the distribution of microborings at smaller magnification (for example, related with banding).

The cathodoluminescence microscopy was not applicable for the samples studied, but is potentially useful for the detection of microborings filled with calcite cement, as studies of post-mortem borings in carbonate substrates showed (e.g., Reolid and Benito 2012). CL microscopy, as well as fluorescence microscopy is recommended if the etching of thin-sections is not possible.

All of these methods require studies of thin-sections, which are not covered by a glass slide. It is beyond of the scope of this paper, but it should be kept in mind that microborings thinner than $5 \mu \mathrm{m}$, can be preserved as natural casts, and can also be observed in covered, thin-sections under a petrographic microscope. Corals described by Cenomanian of Saxony (Löser 2014), contain abundant ferruginous casts of diverse microborings, produced in living corals and post-mortem (preliminary results: Salamon 2017; Salamon et al. 2018).

The acid-etched thin-sections allow ichnotaxonomic studies under SEM SE. If the material available for study is limited, only small parts of thin-section can be etched. SEM BSE may be another method for the imaging of microborings, both in etched and (mainly) non-etched thin-sections. However, much more important is that SEM BSE is a useful tool for the visualization of cement-filled microborings. LMC cement-filled microborings were revealed by SEM BSE in aragonitic skeletons of modern corals (Nothdurft et al. 2007; Nothdurft and Webb 2009). Both SEM BSE and $\mathrm{CL}$ are important methods for detection of calcitefilled microborings (and fractures) even in perfectly preserved modern corals, if corals are utilized as archives of geochemical proxies (Nothdurft et al. 2007; Nothdurft and Webb 2009).

Our studies dealt with a simple methodology for the detection of the microborings produced by in vivo associated microendoliths. However, all the tested methods can also be applied for rapid detection as well as better documentation of microborings produced post-mortem in various substrates.

Acknowledgements We thank Gudrun Radtke (Wiesbaden) and Hilmar Schnick (Putbus) for their helpful and critical reviews. We also thank Mariusz Kępczyński for valuable suggestions about the fluorescence microscopy. The present research is a contribution to the grant of a National Science Centre of Poland (Project No. 2016/23/N/ ST10/01334) provided for K. Salamon. It was also partly supported by the grant of a Polish Ministry of Science and Higher Education (6 P04 015 11, for B. Kołodziej) and grant from Jagiellonian University (DS/ MND/WGiG/ING/2017/10 for K. Salamon).

Open Access This article is distributed under the terms of the Creative Commons Attribution 4.0 International License (http://creativeco mmons.org/licenses/by/4.0/), which permits unrestricted use, distribution, and reproduction in any medium, provided you give appropriate credit to the original author(s) and the source, provide a link to the Creative Commons license, and indicate if changes were made.

\section{References}

Bitner MA, Müller A (2017) Late Eocene (Priabonian) brachiopod fauna from Dnipropetrovsk, eastern Ukraine. Bull Geosc 92:211231. https://doi.org/10.3140/bull.geosci.1661

Carilli JE, Godfrey J, Norris RD, Sandin SA, Smith JE (2010) Periodic endolithic algal blooms in Montastraea faveolata corals may represent periods of low-level stress. B Mar Sci 86:709-718

Casanova Municchia A, Percario Z, Caneva G (2014) Detection of endolithic spatial distribution in marble stone. J Microsc 256:3745. https://doi.org/10.1111/jmi.12155

Chazottes V, Cabioch G, Golubic S, Radtke G (2009) Bathymetric zonation of modern microborers in dead coral substrates from New Caledonia-implications for paleodepth reconstructions in Holocene corals. Palaeogeogr Palaeoclimatol Palaeoecol 280:456-468. https://doi.org/10.1016/j.palaeo.2009.06.033 
Elias RJ, Lee D-J (1993) Microborings and growth in Late Ordovician halysitids and other corals. J Paleontol 67:922-934. https://doi. org/10.1017/S0022336000025221

Fine M, Loya Y (2002) Endolithic algae - an alternative source of energy during coral bleaching. Proc Biol Sci 269:1205-1210. https://doi.org/10.1098/rspb.2002.1983

Försterra G, Beuck L, Häussermann V, Freiwald A (2005) Shallowwater Desmophyllum dianthus (Scleractinia) from Chile: characteristics of the biocoenoses and the bioeroding community, heterotrophic interactions and (paleo)-bathymetric implications. In: Freiwald A, Roberts JM (eds) Cold-water Corals and Ecosystems. Springer, Berlin Heidelberg, pp 937-977. https://doi. org/10.1007/3-540-27673-4_48

Golubic S, Brent G, Le Campion T (1970) Scanning electron microscopy of endolithic algae and fungi using a multipurpose casting embedding technique. Lethaia 3:203-217. https://doi. org/10.1111/j.1502-3931.1970.tb01858.x

Golubic S, Friedmann I, Schneider J (1981) The lithobiontic ecological niche, with special reference to microorganisms. J Sediment Petrol 51:475-478. https://doi.org/10.1306/212F7CB6-2B2411D7-8648000102C1865D

Golubic S, Radtke G, Le Campion-Alsumard T (2005) Endolithic fungi in marine ecosystems. Trends Microbiol 13(5):229-235. https:// doi.org/10.1016/j.tim.2005.03.007

Gutner-Hoch E, Fine M (2011) Genotypic diversity and distribution of Ostreobium quekettii within scleractinian corals. Coral Reefs 30:643-650. https://doi.org/10.1007/s00338-011-0750-6

Kołodziej B, Radtke G (1999) Relation of coral microstructure and microendoliths attack (Paleocene). In: 8th international symposium on Fossil Cnidaria and Porifera, Sendai, September 12-16, 1999, Abstracts, pp 101

Kołodziej B, Stolarski J (2000) Paleoceńskie koralowce z "iłów babickich" (in Polish). In: XVII Konferencja Paleontologów, Kraków, 21-23.09.2000. Kraków, pp 46-47

Kołodziej B, Golubic S, Bucur II, Radtke G, Tribollet A (2012) Early Cretaceous record of microboring organisms in skeletons of growing corals. Lethaia 45:34-45. https://doi.org/10.111 1/j.1502-3931.2011.00291.x

Kołodziej B, Idakieva V, Ivanov M, Salamon K (2016) New record of endolithic algae syn vivo associated with an Early Cretaceous coral. Carnets Geol 16(27):633-640. https://doi. org/10.4267/2042/61885

Krach W (1969) Mollusca of the Babica Clays (Paleocene) of the Middle Carpathians. Pt. II. Pelecypoda. Stud Geol Pol 29:1-80

Kuzmicheva EI (1987) Verhnemelovye i paleogenovye korally SSSR. [Upper Cretaceous and Paleogene corals of the USSR]. Nauka, Moscow (in Russian)

Le Campion-Alsumard T, Golubic S, Hutchings P (1995) Microbial endoliths in the skeletons of live and dead corals: Porites lobata (Moorea, French Polynesia). Mar Ecol Prog Ser 117:149-157. https://doi.org/10.3354/meps117149

Lichtman JW, Conchello J-A (2005) Fluorescence microscopy. Nat Methods 2:910-919. https://doi.org/10.1038/nmeth817

Löser H (2014) Korallen. Geologica Saxonica 60:17-56

Makarenko DE, Zelinskaya VA, Zernetsky BF et al (1987) Stratigraficheskaja shema paleogenovyh otlozhenij Ukrainy (unificirovannaja). Naukova Dumka, Kiev (In Russian)

McFadden PD, Frederick K, Argüello LA, Zhang Y, Vandiver P, Odegaard N, Loy DA (2017) UV fluorescent epoxy adhesives from noncovalent and covalent incorporation of coumarin dyes. ACS Appl Mater Interfaces 9:10061-10068. https://doi.org/10.1021/ acsami.6b13218

Nielsen JK, Maiboe J (2000) Epofix and vacuum: an easy method to make casts of hard substrates. Palaeontol Electron 3(1):1-10

Nosovsky MF (1978) Novoe mestonahozhdenie mandrikovskih sloev v rajone g. Dnepropetrovska i ih paleontologicheskaja harakteristika. In: Nosovsky MF, Konenkova ID, Barg IM, Bogdanovich EM (eds) Stratigrafija kajnozoja Severnogo Prichernomor'ja i Kryma (in Russian). Izdatel'stvo Dnepropetrovskogo universiteta, Dnepropetrovsk, pp 40-48

Nothdurft LD, Webb GE (2009) Earliest diagenesis in scleractinian coral skeletons: implications for palaeoclimate-sensitive geochemical archives. Facies 55:161-201. https://doi.org/10.1007/ s10347-008-0167-z

Nothdurft LD, Webb GE, Bostrom T, Rintoul L (2007) Calcitefilled borings in the most recently deposited skeleton in livecollected Porites (Scleractinia): implications for trace element archives. Geochim Cosmochim Acta 71:5423-5438. https://doi. org/10.1016/j.gca.2007.09.025

Pagel M, Barbin V, Blanc P, Ohnenstetter D (eds) (2000) Cathodoluminescence in geosciences. Springer, Berlin, Heidelberg

Perry CT, Macdonald IA (2002) Impacts of light penetration on the bathymetry of reef microboring communities: implications for the development of microendolithic trace assemblages. Palaeogeogr Palaeoclimatol Palaeoecol 186:101-113. https://doi.org/10.1016/ S0031-0182(02)00446-7

Pica D, Tribollet A, Golubic S, Bo M, Di Camillo CG, Bavestrello G, Puce S (2016) Microboring organisms in living stylasterid corals (Cnidaria, Hydrozoa). Mar Biol Res 12:573-582. https://doi. org/10.1080/17451000.2016.1169298

Radtke G (1991) Die mikroendolithischen Spurenfossilien im AltTertiär. West-Europas und ihre palökologische Bedeutung. Cour Forsch Senck 138:1-185

Radtke G, Campbell SE, Golubic S (2016) Conchocelichnus seilacheri igen. et isp. nov., a complex microboring trace of bangialean rhodophytes. Ichnos 23(3-4):228-236. https://doi.org/10.1080/10420 940.2016.1199428

Rajchel J (1990) Litostratygrafia osadów górnego palecenu i eocenu jednostki skolskiej (in Polish). Zeszyty Nauk. AGH Geol 48:1-11

Reolid M, Benito MI (2012) Belemnite taphonomy (Upper Jurassic, Western Tethys) Part I: biostratinomy. Palaeogeogr Palaeoclimatol Palaeoecol 358:72-88. https://doi.org/10.1016/j.palae o.2012.06.012

Risk MJ, Pagani SE, Elias RJ (1987) Another internal clock: preliminary estimates of growth rates based on cycles of algal boring activity. Palaios 2:323-331. https://doi.org/10.2307/3514757

Roniewicz E (1984) Aragonitic Jurassic corals from erratic boulders on the south Baltic coast. Ann Soc Geol Pol 54:65-77

Roniewicz E, Stolarski J (1991) Miocene scleractinia from the Holy Cross Mountains, Poland; part 2-Archaeocoeniina, Astraeina, and Fungiina. Acta Geol Pol 41:69-84

Salamon K (2017) Boring activity of symbiotic microorganisms in Cenomanian and Paleocene corals: preliminary results. In: 9th International Bioerosion Workshop Rome, October 23rd-27th, 2017, Book of abstracts. Istituto Superiore per la Conservazione ed il Restauro, Rome, pp 85-87

Salamon K, Kołodziej B, Löser H, Radtke G (2018) Microborings produced by coral-associated microendoliths from the Cenomanian of Dresden (Saxonian-Bohemian Cretaceous Basin). In: Pšenička J, Frojdová J, Svobodová A, Dašková J (eds): 19th Czech-SlovakPolish Palaeontological Conference and MIKRO 2018 workshop Prague, October 18-19, 2018; Abstract Book (Folia Musei rerum naturalium Bohemiae occidentalis. Geologica et, special volume 2018). West Bohemian Museum in Pilsen, Plzeň, pp 75-76

Stefanskyi VL (2015a) The paleogeographic, lithological and facial peculiarities of Mandrykovska Strata formation in Dnipropetrovsk (Upper Eocene, Ukraine) (in Russian with English summary). Visn Dnipropetr Univ Ser Geol Geogr 23:125-136. https://doi. org/10.15421/111517

Stefanskyi VL (2015b) Tafonomicheskie aspekty issledovanija mandrykovskih sloev verhnego jeocena (g. Dnepropetrovsk, Ukraina) [Taphonomic aspects of the study of the Mandrykovka Beds of 
the Upper Eocene (Dniepropetrovsk, Ukraine] (In Russian). Bull Kharkiv Natl Univ Ser Geol Geogr Ecol 42(1157):58-62. https:// doi.org/10.13140/RG.2.1.3812.9527

Stefanskyi VL, Udovichenko NI, Stefanskyi MV, Bratishko AV (2011) O litologicheskom sostave i stratigraficheskom obyome mandrikovskih sloev g. Dnepropetrovska. Problemy stratygrafii' i koreljacii' fanerozojs'kyh vidkladiv Ukrai'ny (in Russian). In: Materialy XXXIII sesii' Paleontologichnogo tovarystva NAN Ukrai'ny (Kiev 6-8 cherv. 2011). Natsional'na Akademiya Nauk Ukrayiny, Kiev, pp 74-75

Studencka B (1986) Bolesław Kropaczek—odkrywca iłów babickich (in Polish). Pr Muz Ziemi 38:93-128

Szczechura J, Pożaryska K (1974) Foraminiferida from the Paleocene of Polish Carpathians (Babica Clays). Palaeontol Pol 31:1-142

Tribollet A (2008) The boring microflora in modern coral reef ecosystems: a review of its roles. In: Wisshak M, Tapanila L (eds) Current Developments in Bioerosion. Springer, Berlin, Heidelberg, pp 67-94. https://doi.org/10.1007/978-3-540-77598-0

Tribollet A, Payri C (2001) Bioerosion of the crustose coralline alga Hydrolithon onkodes by microborers in the coral reefs of Moorea, French Polynesia. Oceanol Acta 24:329-342. https://doi. org/10.1016/S0399-1784(01)01150-1

Tribollet A, Radtke G, Golubic S (2011) Bioerosion. In: Reitner J, Thiel V (eds) Encyclopedia of Geobiology. Springer, Dordrecht, pp 117-134
Verbruggen H, Tribollet A (2011) Boring algae. Curr Biol 21:876-877. https://doi.org/10.1016/j.cub.2011.09.014

Veselov AA, Golev BT, Ljul'eva SA, Savenko NG, Sheremeta VG (1974) Novye dannye o stratigraficheskom polozhenii i vozraste mandrikovskih sloev okrestnostej g. Dnepropetrovska (USSR) (in Russian). Dokl Akad Nauk SSSR 217(5):1145-1147

Vogel K, Marincovich L Jr (2004) Paleobathymetric implications of microborings in Tertiary strata of Alaska, USA. Palaeogeogr Palaeoclimatol Palaeoecol 206:1-20. https://doi.org/10.1016/j.palae o.2003.12.017

Vogel K, Gektidis M, Golubic S, Kiene WE, Radtke G (2000) Experimental studies on microbial bioerosion at Lee Stocking Island, Bahamas and One Tree Island, Great Barrier Reef, Australia: implications for paleoecological reconstructions. Lethaia 33:190 204. https://doi.org/10.1080/00241160025100053

Wisshak M (2006) High-latitude bioerosion: the Kosterfjord experiment. Lecture notes in earth sciences, vol 109. Springer, Berlin, Heidelberg. https://doi.org/10.1007/978-3-540-36849-6

Wisshak M (2012) Chapter 8: Microbioerosion. In: Knaust D, Bromley RG (eds) Trace fossils as indicators of sedimentary environments, developments in sedimentology, vol 64. Elsevier, Amsterdam, pp 213-243 